\title{
Smart City Kota Magelang : Perubahan Manajemen Pemerintahan Daerah dalam Penerapan Electronic Governance
}

\author{
Yuni Kurniasih a1, Tri Asih Wismaningtyas, b2
}

Universitas Tidar, Jalan Kapten Suparman No. 39 Kota Magelang 56116

${ }^{1}$ yunikurniasih@untidar.ac.id; ${ }^{2}$ triasihwismaningtyas@untidar.ac.id

\section{INFO ARTIKEL}

\section{Riwayat Artikel:}

Diterima: 07-08-2020

Disetujui: 24-08-2020

\section{Kata Kunci:}

1. Perubahan manajemen

2.Smart City

3.E-governance
Keyword:

1. Change of management

2. Smart City

3. E-Governance

\begin{abstract}
ABSTRAK
Abstrak: Perspektif governance muncul sebagai solusi atas keterbatasan konsep pemerintah. Perkembangan teknologi yang semakin pintar menjadikan konsep 'smart' tidak hanya diterapkan pada berbagai perangkat, tetapi juga pada berbagai sistem dan tatanan. Sehingga diperlukan perubahan manajemen dengan menghubungkan teknologi informasi pada organisasi pemerintahan. Upaya ini dinilai efektif untuk meningkatkan kinerja pemerintah khususnya dalam pelayanan publik. Penelitian ini menggunakan metode kualitatif. Penelitian ini bertujuan untuk mengetahui bagaimana perubahan tata kelola Kota Magelang sebagai kota pintar dan untuk mengetahui apakah semua komponen lingkungan pemerintah dan masyarakat sudah siap dengan keberadaan kota pintar. Hasil dari penelitian ini adalah perubahan tata kelola Kota Magelang sebagai smart city telah dimulai. Yaitu dapat dianalisis dalam bentuk kerangka berpikir perubahan, perubahan struktur, pemberdayaan kembali, dan pembaharuan. Kesiapan Pemerintah Kota Magelang memang sudah ada untuk menghadapi sebagai kota pintar, namun masih perlu lebih ditingkatkan lagi. Oleh karena itu, dalam pelaksanaan program kota pintar, Pemerintah Kota Magelang harus mendorong sosialisasi kepada masyarakat bahwa ada bentuk pelayanan publik melalui pemanfaatan teknologi informasi dan musyawarah kepada stakeholders guna tercipta kerjasama untuk mewujudkan konsep smart city di Kota Magelang yang sebenarnya.
\end{abstract}

Abstrac: Governance perspective appears as a solution to the limitations of the government's concept. The development of increasingly smart technologies makes the concept of 'smart' not only applied to a variety of devices, but also to various systems and orders. So that management changes by linking information technology in government organizations are needed. This effort is considered effective to improve government performance, especially in public services. This research using qualitative methods. This aims of this research is to find out how management changes of the Magelang City as a smart city and to find out whether are all components of both the government environmental and the communities are ready for the existence of smart city. The results of this research are management changes of Magelang City as smart city has begun. That is can be analyzed in the form of framework thinking changes, changing the structure, re-empowerment, and renewal. Readiness of the government of Magelang City is already exist to confront as smart city, but it still needs 
more improvement. Therefore, in the implementation of smart city program, the government of Magelang City should encourage socialization to the society that there is a form of public service through utilize information technology and carry out deliberations on it to stakeholders in order to create cooperation to realize the actual concept of smart city in Magelang City.

\section{LATAR BELAKANG}

Pemerintah daerah saat ini dituntut untuk melakukan pembaharuan di berbagai sektor sebagai suatu langkah untuk mengatasi tuntutan masyarakat yang semakin kompleks. Perubahan manajemen di sektor pemerintah menjadi suatu keharusan yang dilakukan agar keberadaan pemerintah menjadi bermakna di mata rakyatnya.

Peraturan Menteri Pemberdayaan Aparatur Negara dan Reformasi Birokrasi Nomor 10 Tahun 2011 tentang Pedoman Pelaksanaan Program Perubahan Manajemen mendefinisikan perubahan manajemen merupakan pengelolaan sumber daya dalam rangka mencapai tujuan organisasi dengan kinerja yang lebih baik. Perubahan dalam konteks ini yaitu perubahan manajemen dari pemerintahan konvensional menuju e-governance yaitu dengan membuat inovasi-inovasi, salah satunya yaitu dengan transformasi perubahan manajemen pemerintah. Transformasi pada dasarnya merupakan proses yang berlangsung terus-menerus. Transformasi ini meliputi mengkerangka ulang/refroming, menstruktur ulang/restructuring, menyusun-ulang prioritas pembangunan/ revitalization dan pembaharuan/ renewal. [1]

Perkembangan teknologi yang semakin maju membuat suatu perubahan konsep 'smart' yang tidak hanya diterapkan pada berbagai perangkat, tetapi pada berbagai sistem atau tatanan. Salah satunya yang sedang diterapkan akhir-akhir ini adalah konsep smart city sebagai salah satu penerapan dari e-governance. Konsep yang disebut kota pintar ini adalah konsep yang mengutamakan sebuah tatanan kota cerdas yang dapat berperan dalam memudahkan masyarakat untuk mendapatkan informasi secara tepat dan cepat. [2]

Pemerintah telah meluncurkan program Indeks Kota Cerdas Indonesia (IKCI) pada tahun 2015. Program tersebut sebagai salah satu cara dalam rangka peningkatan kinerja Penyelenggaraan Pemerintah Daerah. Pemerintah Daerah melalui Undang-Undang Nomor 23 Tahun 2014 tentang Pemerintahan Daerah dalam Bab XXI bertajuk Inovasi Daerah. Dari Pasal 386 hingga Pasal 390 UU 23/2014, menjelaskan bahwa dalam rangka peningkatan kinerja penyelenggaraan pemerintahan daerah, pemerintah daerah dapat melakukan inovasi. Inovasi yang dimaksud adalah semua bentuk pembaharuan dalam penyelenggaraan pemerintah daerah. Dengan diselenggarakan program tersebut, maka kota-kota di Indonesia berlomba-lomba untuk memperbaiki tatanan kota dengan menerapkan program Smart City.

Dengan pesatnya kemajuan media dan teknologi yang ada, Kota Magelang sebagai kota yang tingkat pertumbuhan dan perkembangan semakin tinggi membutuhkan sistem perkotaan yang lebih mumpuni. Konsep pengembangan kota cerdas di Kota Magelang ini mengacu pada rencana induk yang telah disusun oleh pemerintah pusat pada tahun 2016. Konsep ini dikenal dengan Garuda Smart City Model (GSCM). Sebuah konsep kota cerdas yang dipakai untuk menilai tingkat kematangan kota-kota di Indonesia. Konsep kota cerdas dalam GSCM terdiri atas tiga komponen, yaitu cerdas secara ekonomi, kecerdasan pengelolaan lingkungan, dan kecerdasan lingkungan. Dalam hal ini, ketiganya harus seimbang. Oleh karena itu, di zaman yang serba digital ini, kemampuan pengawasan dari pihak pemerintah kota perlu diupgrade. Pemerintah Kota Magelang saat ini sedang mengembangkan program Smart City dalam rangka memajukan daerah dan mensejahterakan masyarakatnya. [6]

Hal tersebut dibuktikan dengan dinobatkannya Kota Magelang sebagai Kota Cerdas dalam Indeks Kota Cerdas Indonesia (IKCI) 2015. Selanjutnya Kota Magelang juga meraih penghargaan sebagai 
Kota Cerdas Ekonomi. Kota Magelang menempati posisi teratas dengan skor 74,196 dalam skala 100 yang mengungguli kota-kota besar seperti Semarang, Yogyakarta, Malang, Surabaya, Bandung, Surakarta dan lainnya. Hal ini menunjukkan bahwa dalam pelaksanaannya pemerintahan Kota Magelang telah melakukan perubahan dalam manajemen pemerintah dan perbaikan kualitas pelayanan publik yang dapat dilihat dari adanya program-program atau aplikasi layanan yang dibuat oleh pemerintah untuk memberikan kemudahan bagi masyarakat.

Terlepas dari prestasi-prestasi yang diraih Kota Magelang sebagai kota cerdas, dalam pelaksanaan program Magelang Smart City ini masih terdapat masalah dan kendala yang belum terselesaikan hingga saat ini yaitu adanya beberapa regulasi dan aturan-aturan lama yang berbenturan dengan faedah konsep smart city. Anggaran yang masih minim untuk memenuhi kebutuhan membangun smart city mengingat harga perangkat yang tinggi dan sukar diperoleh. Tantangan lain yang harus dihadapi adalah mempersiapkan masyarakat untuk menerima perubahan ke arah digitalisasi. Selain itu, masih adanya ego sektoral yang menjadi masalah dalam pelaksanaan smart city padahal untuk mewujudkan konsep smart city dibutuhkan integrasi. Hal ini bisa dilihat dari adanya berbagai aplikasi yang mendukung program smart city biasanya hanya dibuat berdasarkan kebutuhan dan belum memikirkan integrasi penggunaannya. Untuk menciptakan integrasi tersebut harus ada keterbukaan antar pihak-pihak terkait dalam memberikan informasi data.

Hasil penelitian Nurhadryani menjelaskan bahwa terdapat berbagai tantangan yang mungkin akan dihadapi dalam menerapkan program smart city, diantaranya adalah ketersediaan infrastruktur information and communications technology (ICT), data yang terintegrasi, keamanan data dan jaringan sistem, komitmen pemerintah, adanya kebijakan-kebijakan yang menekankan percepatan pembangunan smart city, kapasitas sumber daya manusia, dan ketersediaan ruang fiskal (anggaran) dalam rangka mendukung proses penerapan program smart city, ketimpangan digital dan sulitnya mengubah kebiasaan masyarakat. [6]

Berdasarkan uraian diatas, penelitian ini bertujuan untuk menganalisis bagaimana perubahan manajemen Pemerintahan Kota Magelang dan kesiapan Kota Magelang untuk menghadapi tantangan dalam menerapkan konsep smart city yang sesungguhnya.

\section{TINJAUAN PUSTAKA}

\section{a. E-Governance}

E-Governance adalah penggunaan teknologi informasi dan komunikasi untuk mendukung good governance. E-Governance terdiri dari dua elemen penting yaitu 'governance' sebagai konsep utama dan 'electronic' atau ICTs (information and communication technologies) sebagai alat untuk meningkatkan proses governance. Word Bank menyatakan bahwa e-governance mengacu pada penggunaan teknologi informasi oleh instansi pemerintah yang memiliki kemampuan untuk mengubah hubungan dengan masyarakat, bisnis, dan badan lain dari pemerintah. Teknologi ini dapat melayani berbagai tujuan yang berbeda seperti pemberian pelayanan yang lebih baik oleh pemerintah kepada masyarakat, meningkatkan interaksi dengan bisnis dan industri, pemberdayaan warga melalui akses informasi, dan manajemen pemerintahan yang lebih efisien. Manfaat yang dihasilkan dapat mengurangi korupsi, peningkatan transparansi, kenyamanan yang lebih besar, pertumbuhan pendapatan, dan/pengurangan biaya. [4]

Dengan demikian e-governance dapat diartikan sebagai penggunaan ICTs dalam proses governance dimana terdapat banyak sektor yang terlibat (tidak hanya sektor publik tapi juga sektor privat dan sektor non-pemerintah) serta terjadi antar level governance yang berbeda. Tiap level governance terdiri dari tiga sektor yaitu sektor publik/ pemerintah, sektor privat dan sektor non-pemerintah (organisasi non-profit). Dimensi horizontal menunjukkan hubungan antar tiga sektor tersebut dalam level tertentu, sedangkan dimensi vertikal adalah hubungan antara sektor yang sejenis dalam level yang berbeda misalnya sektor publik di level lokal dan nasional. Selain itu hubungan bisa terjadi 
antar sektor yang berbeda jenis dan antar level yang berbeda pula, misalnya antara sektor publik di level lokal dengan sektor privat di level nasional. [3]

Secara umum, pada e-governance, penggunaan ICTs yang dimaksud adalah menggunakan aplikasi internet seperti websites, email, mailing list dan sebagainya yang dapat digunakan untuk menyebarkan informasi kepada sektor-sektor yang terlibat, menyelenggaraan pelayanan publik kepada sektor yang terkait dan berkomunikasi antar sektor secara elektronik. Masyarakat dapat menerima banyak informasi lebih cepat dan efisien serta dapat berinteraksi dengan pemerintahan maupun sektor lainnya yang tidak terbatas oleh waktu dan jarak dibanding dengan sebelumnya. Tanpa ICTs proses governance sulit atau lamban untuk terwujud. [4]

\section{b. Perubahan Manajemen}

Transformasi manajemen pemerintah pada dasarnya merupakan inovasi-inovasi yang dilakukan oleh pemerintah guna mengadakan perubahan di bidang struktural dan prosedural. Inovasi struktural berhubungan dengan perubahan yang menyangkut kelembagaan, sementara inovasi prosedural berhubungan dengan berbagai perubahan di bidang mekanisme kepemerintahan.

Inovasi-inovasi dalam transformasi tersebut, meliputi re-framing, re-structuring, re-vitalizaton dan re-newal. Sebagai suatu proses yang mendahului berbagai perubahan-perubahan tersebut. [1]

1. Reframing (pengubahan kerangka berpikir) yaitu suatu dimensi transforming organisasi dalam peningkatan konsepsi organisasi (company) tentang sesuatu masalah yang dihadapi dan bagaimana langkah-langkah yang perlu ditempuh untuk mengatasinya. Organisasi sering memperoleh cara tertentu dari pemikiran yang kurang tepat dan kehilangan kemampuan untuk mengembangkan model-model pemikiran baru (alternatif) tentang masalah apa sebenarnya yang dihadapi dan apa saja yang dapat diperbuat. Dengan demikian, organisasi selalu berusaha membuka pikiran serta memasukkannya dalam visi baru dalam rangka mengantisipasi masalah- masalah internal dan eksternal organisasi yang terus menerus berubah.

2. Retructuring (pengubahan struktur) yaitu suatu dimensi transformasi organisasi pada suatu organisasi menghadapi persaingan kinerja (performance) dengan cara mengubah besaran agar organisasi dapat berjalan dengan lincah. Pertimbangan utamanya adalah bagaimana mengatur keseimbangan dalam organisasi. Jadi dalam hal ini organisasi selalu menggunakan keunggulan untuk menerapkannya dalam program-program perubahan (transformation) dalam jangka waktu yang lebih lama.

3. Revitalization (memberdayakan kembali) merupakan suatu dimensi transformasi organisasi dimana organisasi memelihara pertumbuhannya dengan cara mengaitkan besaran organisasi terhadap lingkungan organisasi. Untuk meningkatkan pertumbuhan organisasi harus pula diperhatikan sumber-sumber daya yang tersedia.

4. Renewal (pembaharuan) yaitu suatu dimensi transformasi organisasi yang beroriensasi pada transformasi orang (people) dan jiwa dari organisasi, dengan cara membangun keahlian dan tujuan baru, sehingga organisasi dapat mengatasi dirinya sendiri.

\section{c. Smart City}

Smart city adalah konsep perencanaan kota dengan memanfaatkan perkembangan teknologi yang akan membuat hidup yang lebih mudah dan sehat dengan tingkat efisiensi dan efektivitas yang tinggi. Smart city didefinisikan juga sebagai kota yang mampu menggunakan sumber daya manusia, modal sosial, dan infrastruktur telekomunikasi modern untuk mewujudkan pertumbuhan ekonomi berkelanjutan daya yang bijaksana melalui pemerintahan berbasis partisipasi masyarakat. Modal utama dalam penerapan smart city adalah investasi modal manusia dan sosial, dengan transportasi dan infrastruktur komunikasi modern serta pembangunan ekonomi yang berkelanjutan dan kualitas hidup yang tinggi, dengan manajemen SDA yang bijaksana melalui tata pemerintahan yang partisipatif. Kota Cerdas atau Smart City pada umumnya didasarkan pada 3 hal, yaitu: pertama 
faktor manusia, kota dengan manusia-manusia yang kreatif dalam pekerjaan, jejaring pengetahuan, lingkungan yang bebas dari kriminal. Faktor kelembagaan, masyarakat kota (pemerintah, kalangan bisnis dan penduduk) yang memahami teknologi informasi dan membuat keputusan berdasarkan pada teknologi informasi menurut Ahmad Nurmandi membagi smart city ke dalam enam indikator, yaitu: smart people, sm art environment, smart living, smart economy, smart governance. [8]

\section{METODE PENELITIAN}

Peneliti menggunakan tipe penelitian deskriptif dengan pendekatan kualitatif. Jenis data yang digunakan yaitu data yang berbentuk teks dan data yang berbentuk kata-kata. Adapun sumber data terdiri dari sumber data primer yang berasal dari wawancara terhadap informan dan sumber data sekunder yang berasal dari dokumen, jurnal ilmiah, data statistik, laporan dan lain-lain yang berhubungan dengan penelitian ini.

Teknik Pengumpulan data melalui wawancara dan studi kepustakaan. Data yang diperoleh dari informan selanjutnya dianalisis secara sistematis dengan melakukan tiga langkah secara bersamaan yaitu kondensasi data, penyajian data, penarikan kesimpulan dan verifikasi. Penelitian ini menggunakan teknik pemeriksaan keabsahan data berdasarkan teknik triangulasi dengan sumber yang berarti membandingkan dan mengecek balik derajat kepercayaan suatu informasi yang diperoleh melalui waktu dan alat yang berbeda dalam penelitian kualitatif.

\section{PEMBAHASAN}

\section{a. Perubahan Manajemen Pemerintah Magelang}

Perubahan manajemen telah diatur dalam Peraturan Pemerintah Nomor 81 tahun 2010 tentang Grand Desain Reformasi Birokrasi. Kemudian diatur lebih lanjut dengan aturan pelaksanaannya antara lain Peraturan Menteri Pendayagunaan Aparatur Negara dan Reformasi Birokrasi Nomor 10 tahun 2011 tentang Pedoman Pelaksanaan Program Perubahan Manajemen. Perubahan manajemen dilaksanakan untuk memperoleh pemahaman yang sama dan mengurangi resistensi dari pegawai serta memastikan partisipasi pegawai dan masyarakat umum dalam mewujudkan pemerintahan yang baik. Proses perubahan manajemen disini berfokus pada perubahan manajemen e-government menjadi e-governance, dimana dalam pelaksanaannya memanfaatkan teknologi informasi dan komunikasi dalam penerapan smart city. Penerapan program smart city di Kota Magelang telah menjadi perencanaan pemerintah Kota Magelang yang tertuang di dalam RPJMD Kota Magelang tahun 2016-2020. Penerapan smart city di Kota Magelang masih dalam tahap awal karena mulai diterapkannya pada tahun 2015. Untuk memajukan masih dalam proses persiapan dan perencanaan, oleh karenanya memakan waktu yang cukup lama dan biaya yang tidak sedikit, serta masih perlunya dukungan dari berbagai pihak terutama masyarakat. Masyarakat juga perlu memahami konsep dari smart city yang dapat diperoleh melalui sosialisasi dari pemerintah maupun media massa. Inovasi-inovasi dalam transformasi/perubahan manajemen di Kota Magelang tersebut, meliputi:

1. Refarming

Refarming membahas tentang pikiran organisasi. Organisasi sering kali kehilangan kemampuan untuk mengembangkan model mental baru dari identitas mereka dan apa yang akan mereka raih. Reframing membuka pemikiran organisasi dan mempercayakan visi baru dan ketentuan baru. [4]

Perwujudan dari konsep refarming dapat dilihat dari visi dan misi Kota Magelang yang merupakan gambaran umum Kota Magelang dalam 5 (lima) tahun mendatang. Visi Kota Magelang pada Tahun 2010-2015 adalah “Terwujudnya Kota Magelang sebagai Kota Jasa yang Maju, Profesional, Sejahtera, Mandiri dan Berkeadilan. Kemudian untuk menciptakan Magelang Smart City, Kepala Daerah dan Wakil Kepala Daerah terpilih merumuskan visi dan misi baru dalam rangka pembangunan daerah Kota Magelang tahun 2016-2020 yaitu: "Magelang Sebagai Kota Jasa yang Modern dan Cerdas yang Dilandasi Masyarakat yang Sejahtera dan Religius". 
Unsur yang terkandung dalam visi tersebut yaitu, Magelang sebagai Kota Jasa berarti pembangunan Kota Magelang diarahkan untuk sektor jasa yang didominasi oleh jasa pemerintahan umum dan jasa swasta sebagai potensi kota, dengan menitikberatkan pada sektor perekonomian, sektor kesehatan, dan sektor pendidikan. Kota modern adalah sikap dan cara berfikir serta cara bertindak sesuai dengan tuntutan jaman, yang berarti suatu kondisi lebih maju daripada daerah lain, mampu berdaya saing dengan daerah lain menggunakan potensi yang ada. Dengan kata lain, kota modern adalah kota yang mampu menyelaraskan sosial, fisik, dan ekonomi dengan budaya dan sejarah yang dimiliki oleh kota tersebut.

Konsep smart city mengandung makna kota yang dikelola secara efektif dan efisien untuk memaksimalkan pelayanan kepada warganya secara adil tanpa diskriminasi dengan muatan kemudahan koneksitas informasi yang dilakukan dalam dunia usaha, sistem pelayanan publik, mekanisme partisipasi masyarakat dalam penyampaian aspirasi, kontrol, maupun komplain dan bidang lain pendukung nilai daya saing daerah.

Unsur-unsur kota cerdas yaitu: a) smart governance, yaitu pengembangan e-governance, terdapat partisipasi masyarakat dalam perencanaan pembangunan; b) smart infrastructure, yaitu pengembangan jaringan IT, pengembangan sistem informasi manajemen berbasis IT; c) Smart economy, yaitu: pengembangan city branding, pengembangan kewirausahaan, pengembangan e-commerce, dan ekonomi kreatif; d) Smart environment yaitu: pengelolaan lingkungan berbasis IT, pengelolaan SDA berbasis IT, pemanfaatan sumber energi terbarukan; e) Smart people yaitu: pendidikan dan pengembangan SDM yang melek teknologi, dan dukungan penelitian, pengembangan karakter sosial budaya masyarakat; serta f) Smart living yaitu: kemudahan akses terhadap layanan pendidikan, kemudahan akses terhadap layanan kesehatan, pengembangan peran media, dan kemudahan akses terhadap jaminan keamanan. [8]
Perwujudan konsep unsur-unsur kota cerdas tertuang melalui misi Kota Magelang untuk memberikan arah dan batasan proses pencapaian tujuan, maka ditetapkan 5 (lima) misi Pembangunan Jangka Menengah Daerah Kota Magelang Tahun 2016-2020 adalah sebagai berikut:

a) Meningkatkan sumber daya manusia aparatur yang berkualitas dan profesional dengan mengoptimalkan kemajuan teknologi sebagai dasar terciptanya pemerintahan daerah yang bersih serta tanggap terhadap pemenuhan aspirasi masyarakat, mampu meningkatkan dan mengelola potensi daerah dalam rangka efektifitas dan efisiensi pelayanan kepada masyarakat didukung partisipasi masyarakat dalam rangka meningkatkan kesejahteraan masyarakat.

b) Mengembangkan dan mengelola sarana perkotaan dan sarana pelayanan dasar di bidang pendidikan, kesehatan dan perdagangan yang lebih modern serta ramah lingkungan.

c) Meningkatkan pemerataan pembangunan infrastruktur perkotaan untuk mendukung pemerataaan pembangunan ekonomi dan kesejahteraan masyarakat.

d) Mengembangkan potensi budaya dan kesenian daerah sebagai landasan pengembangan dan pembangunan pariwisata Kota Magelang.

e) Memperkuat kehidupan beragama dan toleransi antar umat beragama melalui penyelenggaraan kegiatan-kegiatan keagamaan dan peningkatan sarana-prasarana peribadatan sebagai landasan terbangunnya masyarakat madani.

Melalui visi dan misi tersebut, Pemerintah Kota Magelang memasukkan program smart city di RPJMD tahun 2016-2020. Dari hal tersebut dapat dikatakan Kota Magelang mulai bertransformasi menuju e-governance. Berkomitmen untuk membuat perubahanperubahan besar dalam membangun smart city dan tujuan akhirnya yaitu memberikan pelayanan terbaik kepada masyarakat.

\section{Retructuring}


Restructuring diibaratkan seperti organisasi yang mengencangkan ikat pinggang, memacunya untuk mencapai level kinerja yang kompetitif. Restructuring berhubungan dengan badan organisasi, dan tingkat daya saing kebutuhan agar organisasi ramping struktur dan sehat merupakan pertimbangan yang utama.

Dengan munculnya Magelang sebagai kota cerdas terdapat perubahan struktur anggaran daerah dimana beberapa OPD mengalami kenaikan dan penurunan anggaran. APBD Kota Magelang setiap tahun dalam waktu tahun 2015 sampai dengan tahun 2019 mengalami kenaikan $7,72 \%$, nilai rata-rata ini masih berpotensi meningkat karena besaran APBD khusus untuk tahun 2018 merupakan APBD sebelum perubahan berbeda dengan APBD tahun sebelumnya. Anggaran litbang mengalami kenaikan cukup besar dibandingkan dengan perangkat daerah yang lainnya yaitu 9,79\% asumsi kenaikan ini dipicu dari diberlakukannya penataan perangkat daerah yang dimulai 1 Januari 2017 dimana anggaran meningkat strukturnya menjadi dikelola oleh Kantor Penelitian Pengembangan dan Statistik.

Pengelolaan kota modern dan cerdas dikendalikan oleh Badan Perencanaan Pembangunan Daerah dengan rata-rata anggaran perencanaan meningkat sebesar $7,74 \%$. Anggaran perindustrian Perdagangan Pasar Koperasi dan Usaha Kecil Menengah (Perindagkop UKM) mengalami kenaikan pula dengan rata-tata sebesar $8,54 \%$, nilai ini merupakan nilai akumulasi perangkat daerah mulai tahun 2017 karena penataan organisasi pada tahun tersebut. Kenaikan anggaran Bidang Perhubungan sebesar $1,74 \%$ karena pada tahun 2017 terjadi penataan dan ada perubahan struktur lembaga yang menangani masalah perhubungan. Rata-rata kenaikan anggaran Lingkungan Hidup (LH) sebesar 10,31\% merupakan penggabungan dari dua lembaga sejak tahun 2017 yang mendongkrak struktur dan berimbas terhadap besaran anggaran yang dikelola oleh lembaga lingkungan hidup. Untuk anggaran Bidang Kesehatan rata-rata kenaikan per tahun sebesar 8,76\% dan anggaran Bidang Pendidikan rata-rata menurun sebesar $2.12 \%$, penyumbang penurunan mulai tahun 2017 dikarenakan pengelolaan sekolah menegah tingkat atas dilakukan oleh pemerintah provinsi setelah sebelumnya masih ditangani oleh pemerintah kota. [7]

\section{Revitalization}

Revitalition berhubungan dengan memacu pertumbuhan dengan mengaitkan badan organisasi ke lingkungan. Dari ke empat R, revitalizazion merupakan faktor tunggal terbesar yang secara jelas membedakan transformasi dari sekedar perampingan organisasi.

Di Kota Magelang hal-hal yang perlu diberdayakan kembali dapat dilihat berdasarkan evaluasi terhadap program kerja yang telah terlaksana/sedang berjalan. Hal-hal yang perlu diberdayakan yaitu dalam kaitannya pelaksanaan program pembangunan yang mana berhubungan dengan pencapaian sasaran visi dan misi pembangunan Kota Magelang. Dengan mengoptimalkan pengunaan teknologi informasi dalam layanan smart city yang menjadi salah satu prioritas pembangunan. Berikut beberapa program Kota Cerdas yang menjadi prioritas:

a) Program sarana dan prasarana bidang teknologi informatika, terdiri dari cakupan data yang terpusat dan terkendali, persentase pemerintah daerah yang menerapkan $e$ government dan cakupan WAN kota.

b) Program pemanfaatan ruang, yaitu persentase infrastruktur yang memenuhi standar aksesbilitas untuk semua.

c) Program optimalisasi pemanfaatan teknologi informasi yaitu pertumbuhan pemanfaatan $e$ commerce bagi UKM.

Salah satu program revitalisasi yang telah dilaksanakan oleh Pemerintah Kota Magelang untuk menunjang smart city yaitu contohnya Pemerintah Kota Magelang memasang CCTV diberbagai sudut kota, pemasangan Wifi gratis di beberapa tempat umum, penyediaan aplikasi data terintegrasi yaitu Magelang data-go, transparansi penyelenggaraan program dan anggaran pemerintah melalui media online, pemanfaatan kanal akses online dalam pelaksanan musrenbang yang mana pihak swasta dan masyarakat umum diberikan kebebasan untuk 
menyalurkan aspirasi dan kebutuhannya kepada pemerintah. Adanya revitalisasi tersebut didasarkan pada salah satu tujuan pengembangan konsep Smart City di Kota Magelang.

4. Renewal

Renewal berurusan dengan sisi manusia dari transformasi, dan semangat dari organisasi. Renewal berkaitan dengan memberikan individuindividu kemampuan-kemampuan dan tujuantujuan baru, sehingga memungkinkan organisasi untuk memperbarui dirinya sendiri.

Hampir di semua bidang dalam Pemerintahan Kota Magelang memerlukan pembaharuan terutama dalam peningkatan kualitas sumber daya manusia (SDM). Salah satu contohnya yaitu Pertama, anggota Dharma Wanita Persatuan Kota Magelang dituntut meningkatkan kualitasnya dalam pekerjaan maupun mendukung kinerja suami. Para istri Aparatur Sipil Negara juga harus peka terhadap kemajuan teknologi informasi. Mereka dituntut kreatif, berinovasi, serta melek teknologi di jaman serba canggih dan modern ini. Kedua, BLK di Kota Magelang telah menghadirkan pelatihan komputer, di mana peserta merupakan warga Kota Magelang dari berbagai kalangan. Dengan hibauan kepada ASN di Kota Magelang yang mulai dituntut untuk paham akan teknologi mampu memaksimalkan kinerjanya. Tidak hanya itu, pelatihan-pelatihan yang dilakukan oleh pemerintah dapat membantu masyarakat dalam pemanfaatan teknologi.

\section{b. Pelaksanaan Smart City di Kota Magelang}

Smart city model atau SCM adalah suatu konsep atau metode awal yang mampu mengukur kesiapan kota/kabupaten dalam merealisasikan konsep smart city. Hasil pengukuran dapat digunakan sebagai dasar untuk pengembangan roadmap smart city. Pemerintah Kota Magelang saat ini tengah mengembangkan program smart city untuk memajukan daerah Kota Magelang dan mensejahterakan masyarakatnya. Penerapan program tersebut telah menjadi perencanaan Pemerintah Kota Magelang yang tertuang dalam RPJMD Kota magelang tahun 2016-2020.
Kota Magelang sendiri mulai menerapkan program smart city sejak tahun 2015 bersamaan dengan dinobatkannya Kota Magelang sebagai Kota Cerdas dalam Indeks Kota Cerdas Indonesia (IKCI) 2015. Dalam penerapan konsep smart city, Kota Magelang mengacu pada penerapan smart city di Kota Bandung dan Kota Surabaya yang telah lebih dahulu dalam menerapkan konsep smart city dan membawa perubahan pada kota tersebut.

Selanjutnya Kota Magelang juga meraih penghargaan sebagai Kota Cerdas Ekonomi. Kota jasa ini menempati posisi teratas dengan skor 74,196 dalam skala 100 yang mengungguli kotakota besar besar seperti Semarang, Yogyakarta, Malang, Surabaya, Bandung, Surakarta dan lainnya. Kemudian di tahun 2017 Kota Magelang Magelang memperoleh berbagai macam penghargaan diantaranya adalah Rating Kesiapan Infrastruktur, Rating Kesehatan Cerdas, Rating Digital Government, Rating Kesiapan Integritas, Rating Ekosistem Inovasi, Rating Keamanan dan Kebencanaan Kota, Rating Sosial Cerdas, Rating Ekonomi Cerdas, Rating Pengembangan dan Pengelolaan Kota, Rating Lingkungan Cerdas, dan Rating mobilitas.

Dari berbagai penghargaan yang telah diperoleh, Kota Magelang terus berkomitmen untuk mewujudkan Kota Cerdas atau Smart City di Indonesia. Konsep pengembangan kota cerdas mengacu pada master plan yang disusun pada tahun 2016, konsep ini dikenal dengan Garuda Smart City Model (GSCM). Konsep kota cerdas dalam GSCM yaitu terdiri dari 3 komponen, yaitu cerdas secara ekonomi, kecerdasan lingkungan, dan kecerdasan pengelolaan lingkungan. Dari predikat yang diperoleh, ketiga konsep tersebut dapat dikatakan di Kota Magelang dalam proses pelaksanaan dan perbaikan.

Contoh dari penerapan konsep cerdas ekonomi yaitu Kota Magelang telah meraih predikat sebagai Kota cerdas ekonomi dalam penghargaan Indeks Kota Cerdas Indonesia (IKCI) 2015. Indikator dari kota cerdas ekonomi sendiri yaitu kelengkapan sarana ekonomi, penurunan kemiskinan, peningkatan kegiatan industri, sumber daya alam, serta SDM dan tingkat pendidikannya. Dalam pelaksanaannya di Kota Magelang sendiri untuk 
memenuhi indikator tersebut, Pemerintah Kota Magelang sudah mennyediakan sarana ekonomi yang layak. Seperti penertiban PKL ditempatkan di wilayah-wilayah kuliner yang baru dibangun oleh pemerintah Kota Magelang. Pemerintah juga berusaha mengadakan pelatihan peningkatan keterampilan bagi pemilik dan karyawan, pelatihan manajemen, pemasaran, hingga fasilitas pameran gratis bagi pengusaha kecil dan makro. Selain itu pemerintah juga mengenalkan perdagangan digital kepada UMKM yang ada agar mampu mengikuti perubahan tren perdagangan masyarakat modern.

Dari segi konsep cerdas lingkungan, Pemerintah Kota Magelang pada tahun 2019 ini kembali memperoleh predikat lingkungan cerdas dari Rating Kota Cerdas Indonesia (RKCI). Saat ini program yang sudah dilaksanakan untuk mencapai konsep cerdas lingkungan yaitu Walikota Magelang meluncurkan Sekolah Pelangi di tiga sekolah dasar dengan berbagai program belajar untuk menanamkan kepada para siswa tentang semangat peduli terhadap lingkungan hidup. Sebagai bentuk realisasi lingkungan cedas, Kota Magelang juga sudah memiliki 96 titik bank sampah yang tersebar di 17 kelurahan. Kemudian jumlah tersebut memiliki sekitar 3.000 nasabah bank sampah aktif. Selain bank sampah, melalui program TPSP sampah yang diangkut ke TPA berhasil dikurangi beberapa persen.

Untuk mewujudkan Magelang Smart City yang sebenarnya, selain pembenahan di sektor ekonomi dan lingkungan, sebagai penentu terpenting kota cerdas yaitu pemerintah juga berusaha meningkatkan pelayanan publik berbasis digital/online. Salah satu upaya yang dilakukan oleh Pemerintah Kota Magelang yaitu dengan meluncurkan fitur BPJS Kesehatan dan Layanan Kesehatan, masyarakat dapat menggunakan fitur ini untuk mendapat berbagai info mengenai lokasi fasilitas kesehatan, pendaftaran online di beberapa rumah sakit di Kota Magelang, kemudian mengecek kamar rumah sakit yang kosong sudah bisa melalui SPGDT (Sistem Penanggulangan Gawat Darurat Terpadu). Melalui SPGDT tersebut pasien dapat melihat ruang bangsal rumah sakit, dan kamar tidur yang kosong. Untuk perbaikan pelayanan bidang kesehatan, Pemerintah Kota Magelang juga menyediakan layanan Call 119, cukup telepon saja apabila membutuhkan tenaga medis dalam keadaan darurat, maka petugas akan menuju ke tempat lokasi untuk memberikan pertolongan.

Kemudian juga disediakan fitur DataGo, sehingga masyarakat dapat mengakses informasi atau mencari data seputar Kota Magelang yang dibutuhkan. Selain itu juga disediakan fitur Harga Komoditas yang dapat digunakan masyarakat untuk mengecek harga bahan kebutuhan pokok dipasaran, data perekonomian, dan lain sebagainya. Penyediaan aplikasi mobile "Magelang Cerdas" yang dilengkapi dengan 20 fitur utama, yaitu Monggo Lapor (dapat diakses masyarakat untuk memberikan berbagai laporan atau keluhan masyarakat mengenai fasilitas jalan, pelayanan umum, dll). Selanjutnya terdapat fitur layanan perizinan, layanan publik, layanan kependudukan, serta layanan pendidikan lainnya.

Namun dalam implementasinya aplikasi ini belum dapat digunakan secara maksimal, fitur-fitur yang disediakan tidak keseluruhan membantu memudahkan masyarakat dalam memperoleh pelayanan. Seperti di dalam fitur Monggo Lapor, masyarakat sudah aktif menggunakannya untuk melaporkan berbagai keluhan seperti air PDAM mati, kondisi jalan yang terputus dan lain-lain. Namun ternyata keluhan-keluhan tersebut tidak secara langsung mendapat respon dari pemerintah, terbukti dengan adanya status pelaporan yang masih terdapat catatan belum ada respon, padahal pelaporan sudah dilakukan dalam kurun waktu beberapa bulan. Hal ini dikarenakan Pemerintah Kota Magelang sampai saat ini belum sepenuhnya bekerja sama dengan OPD terkait sehingga pelayanan yang diharapkan belum dapat terealisasikan. [7]

Kendala lain yang ada yaitu masyarakat belum secara keseluruhan memanfaat aplikasi yang ada, karena sebagian besar masyarakat belum mengetahui adanya aplikasi yang menyediakan berbagai fitur yang mampu memudahkan masyarakat dalam memperoleh pelayanan. Hal ini dikarenakan kurangnya sosialisasi yang diberikan oleh pemerintah kepada masyarakat, peran SDM belum siap dalam menerima perubahan, dan tata kelola yang belum optimal. Untuk mendapatkan 
predikat kota cerdas, Kota Magelang harus mampu mengelola berbagai sumber daya yang dimiliki secara efektif dan efisien dalam menyelesaikan berbagai tantangan kota, menggunakan solusi inovatif, terintegrasi, serta berkelanjutan untuk meyediakan infrastruktur dan memberikan layananlayanan kota yang dapat meningkatkan kualitas hidup warganya.

Selain itu, agenda terstruktur dan komprehensif perlu direncanakan Pemerintah Kota Magelang untuk menerapkan Internet of Thing (IoT) dalam mendukung smart city dan dapat terpadu dengan program pemerintah pusat. Internet of Thing (IoT) adalah sebuah konsep di mana suatu objek yang memiliki kemampuan untuk mentransfer data melalui jaringan tanpa memerlukan interaksi manusia ke manusia atau manusia ke komputer. Dengan IoT, antar objek dapat berkomunikasi dan mampu memudahkan aktivitas manusia. IoT dapat diterapkan dalam smart city sehingga terkoneksi satu sama lain dalam suatu sistem yang komprehensif, yaitu "smart economy", "smart social", "smart environment". Sebuah peran besar menanti bagi organisasi perangkat daerah (OPD) terkait yang tentu saja membutuhkan dukungan dari berbagai pihak di Kota Magelang. Sebelum hal tersebut dilakukan perlunya sebuah koordinasi solid antar OPD dan menyatukan pelayanan mewujudkan smart city yang didukung dengan IoT.

\section{SIMPULAN DAN SARAN}

\section{a. Kesimpulan}

Untuk menerapkan e-governance diperlukan perubahan dalam manajemen pemerintahan salah satunya melalui transformasi yang meliputi mengkerangka ulang/refroming, menstruktur ulang/restructuring, menyusun-ulang prioritas pembangunan/revitalization dan pembaharuan/ renewal serta konsep smart city yang berperan dalam memudahkan masyarakat untuk mendapatkan informasi secara tepat dan cepat. Pemerintah Kota Magelang telah menjadikan Program Kota Cerdas menjadi program prioritas dengan melakukan berbagai revitalisasi potensi-potensi yang ada dan melakukan perubahan dalam struktur anggaran Kota Magelang dalam rangka memajukan daerah Kota Magelang dan mensejahterakan masyarakatnya.
Dalam implementasinya, telah terjadi perubahan meskipun belum menyeluruh. Contoh realisasi dari Magelang smart city antara lain memunculkan Aplikasi Magelang Cerdas, melalui aplikasi tersebut masyarakat dapat mengakses pelayanan rumah sakit melalui SMS, SPGDT (Sistem Penanggulangan Gawat Darurat Terpadu), serta DataGo (masyarakat dapat mengakses informasi atau mencari data seputar Kota Magelang). Namun dalam perkembangannya, penerapan smart city tersebut belum bisa dinikmati oleh seluruh lapisan masyarakat. Hal ini dikarenakan belum adanya koordinasi yang jelas antara pihak pemerintah dengan OPD-OPD yang dibutuhkan, kurangnya sosialisasi yang dilakukan pemerintah kepada seluruh lapisan masyarakat dan masih kurangnya melek masyarakat mengenai pemanfaatan teknologi informasi.

\section{b. Saran}

1. Dalam pelaksanaan program smart city, sebaiknya Pemerintah Kota Magelang memberikan informasi kepada masyarakat yang lebih luas serta mensosialisasikan bahwa telah adanya bentuk pelayanan melalui teknologi informasi, karena masih banyak masyarakat yang belum mengetahui program tersebut.

2. Masih terdapat ego sektoral antar pihak-pihak terkait, sehingga sebaiknya perlu diadakan musyawarah mengenai hal tersebut kepada pihak-pihak terkait agar terciptanya kerjasama untuk mewujudkan konsep smart city yang sebenarnya di Kota Magelang.

3. Sesegera mungkin melakukan kerja sama dengan OPD-OPD yang ada, sehingga pemerintah dalam menciptakan smart city tidak hanya ditunjukkan dengan adanya aplikasi-aplikasi yang diciptakan, namun juga ditunjukkan dengan pelayanan nyata yang dapat diperoleh masyarakat secara online dan nyata dapat dirasakan. 


\section{UCAPAN TERIMA KASIH}

Penulis mengucapkan terima kasih kepada pihak Pemerintah Kota Magelang, terutama kepada Kepala Bappeda Kota Magelang beserta jajarannya yang telah berkenan memberikan data dan informasi sehingga penulis dapat menyelesaikan jurnal penelitian ilmiah ini dengan baik.

\section{DAFTAR RUJUKAN}

\section{Buku}

Gouillart,F.J dan Kelly,J.N. 1995. Transforming The Organization. New York: McGrawHill, Inc.

Hiplunudin, Agus. 2017. Kebijakan, Birokrasi, dan Pelayanan Publik. Yogyakarta: Calpulis

Indrajit, Richardus Eko. 2002. Electronic Government Strategi Pembangunan dan Pengembangan Sistem Pelayanan Publik Berbasis Teknologi Digital. Yogyakarta: Andi

Mark, Bevier. 2007. Encyclopedia of Governance, Vol. I. Los Angeles: Sage Publication

\section{Jurnal}

Muchlas M. Tahir. 2015. Inovasi Pemerintah Daerah Dalam Pelaksanaan Program Smart Card Di Kota Makassar. Makassar: Universitas Muhammadiyah Makassar.

Nurhadryani, Yani. 2009. Memahami Konsep E-Governance serta Hubungannya dengan E-Government dan EDemokrasi. Institute Pertanian Bogor

Oktaviany, Winda. 2018. Inovasi Pemerintah Daerah dalam Pelaksanaan Program Smart City di Kota Magelang . JMAN Universitas Tidar

\section{Artikel/Modul/Diktat}

Ika. 2019. Gamatechno Dukung Pemkot Magelang Kembangkan Program Smart City. Universitas Gadjah Mada

Prasetya, Andjar, Arif Brata Sakti, heny Asmoro, dan M Zaenal arifin. 2018. Bunga Rampai Smart City: Implemantasi Kota Jasa yang Modern dan Cerdas dalam Sistem Perkotaan Inovatif. Magelang: Indocamp. 